ISSN No. $2454-1427$

CDE

January 2021

\title{
Environmental Management Practices and Financial Performance: Evidence from Large Listed Indian Enterprises
}

\author{
Surender Kumar \\ Department of Economics, Delhi School of Economics \\ University of Delhi, Delhi 110007, INDIA \\ E-mail: skumar@econdse.org
}

\section{Pritika Dua}

Department of Business Economics

University of Delhi, South Campus

New Delhi 110021, INDIA

E-mail:pritikadua@gmail.com

\section{Working Paper No. 314}

http://www.cdedse.org/pdf/work314.pdf

\author{
CENTRE FOR DEVELOPMENT ECONOMICS \\ DELHI SCHOOL OF \\ ECONOMICSDELHI1100O7
}




\title{
Environmental Management Practices and Financial Performance: Evidence from Large Listed Indian Enterprises
}

\author{
Surender Kumar ${ }^{1}$ and Pritika Dua ${ }^{2}$ \\ ${ }^{1}$ Department of Economics, Delhi School of Economics \\ University of Delhi, Delhi 110007, INDIA \\ E-mail: skumar@econdse.org \\ \& \\ ${ }^{2}$ Department of Business Economics \\ University of Delhi, South Campus \\ New Delhi 110021, INDIA \\ E-mail:pritikadua@gmail.com
}

\begin{abstract}
Large enterprises have been at forefront of environmental management with active participation in industry wide programs and adoption of 'beyond compliance' approach with more resources at their disposal. The present study revisits the premise of environmental-financial linkage in the Indian context with focus on large listed enterprises. We develop a comprehensive dataset of 459 large listed Indian companies covering major manufacturing and service sectors of the economy over a eleven year period from 2008-09 to 2018-19. Static and dynamic regression models are used to gauge the impact of environmental management practices adoption on firm profitability (Return on Assets and Return on Equity) and market valuation (Tobin Q, Market to Book Value Ratio and Excess Valuation to sales ratio). Empirical results suggest a positive impact of environmental management on firm profitability and market valuation in context of large listed enterprises. These results are of interest to corporate and policy makers for recognizing the financial implications of corporate environmental management.
\end{abstract}

Keywords: Environmental Management Practices, Dynamic panel data models, Firm Valuation, Firm Profitability, Large Enterprises, India 


\section{Environmental Management Practices and Financial Performance: Evidence from Large Listed Indian Enterprises}

\section{Introduction}

Large corporations are progressively making organizational changes to integrate environmental concerns into their manufacturing decisions. With increased pressure from customers, regulators, employees and investors to assume environmental responsibility, they are shifting from a regulation driven reactive approach to a proactive beyond-compliance approach towards environmental management (Khanna \& Damon, 1999; Ervin et al., 2012). Indian companies have been increasingly adopting formalised set of environmental management practices (EMPs). The number of ISO 14001 certified companies in India has soared from meagre 400 in 2001 to 8446 in 2019 (ISO, 2019; CPCB, 2001).

Although corporate move beyond minimum regulations to improve their environmental performance; adoption of EMPs involves costs, firm performance, better reputation and management participation (Curkovic \& Sroufe, 2011). With limited resources at their disposal, firms' interest resides in understanding the financial implications of adoption of EMPs. There is an extensive body of research studying the impact of environmental management on firms' financial performance; both theoretically (Porter \& Van der Linde, 1995; Shahgholian, 2019) and empirically (King \& Lenox, 2001; Konar \& Cohen, 2001; Melnyk et al., 2003; Lucas \& Noordewier, 2016). While some studies deduce a positive relation between the two constructs (Hart \& Ahuja, 1996; King \& Lenox, 2001; Klassen \& McLaughlin, 1996; Konar \& Cohen, 2001; Russo \& Fouts, 1997; Hourneaux et al., 2014; Lucas \& Noordewier, 2016), some others find a negative relation (Wagner et al. 2002; Sariannidis et al., 2013; Chen et al., 2014), and there are some studies that fail to observe any linkage between environmental performance and financial performance (Iraldo et al., 2009; Böhringer et al., 2012; Duque et al., 2020).

The Carbon Majors Report, 2017 states that just hundred large enterprises have been source of more than 70\% of world's greenhouse gas emissions since 1998 (Carbon Disclosure Project Worldwide, 2017). With increasing public awareness and regulatory surveillance, large scale enterprises have become increasingly proactive in environmental management disclosures to improve their legitimacy, reputation and financial performance. While we come across research in Small and Medium Enterprises (SMEs) exploring sustainability and performance, studies on large enterprises are few and numbered (Lee and Klassen, 2008; Zhu et al., 2010; Kliewe et al., 2013; Shashi et al., 2018). To fill in this gap, we make a novel attempt to investigate environment-financial linkage in 459 large listed Indian enterprises over an eleven year period.

This paper contributes to the existing literature on several counts. First, majority of studies examining the relation between environmental and financial performance have been carried in developed nations (Hart \& Ahuja, 1996; Khanna \& Damon, 1999; Klassen \& McLaughlin, 1996; Konar \& Cohen, 2001; Melnyk et al., 2003; Iraldo, Testa \& Frey, 2009; Böhringer et al., 2012). The nature of corporate environmental management in developed countries is very different from developing countries. These countries are characterized by the absence of clear regulations, underdeveloped capital 
markets and inadequate data on emissions (Dasgupta et al., 2001; Dasgupta et al., 2006; Pargal \& Wheeler, 1996; Sarkar \& Sarkar, 2012). Furthermore, only a handful of studies have been conducted in Indian context (Gupta \& Goldar, 2005; Kumar \& Shetty, 2017; Shashi et al., 2019; Singh et al., 2020; Sudha, 2020). Despite regulatory measures in place, ground reality in India is disheartening with weak implementation of existing regulations, non-availability of environmental performance data, poor follow-up of previous regulatory actions and widespread bureaucracy and corruption (Kumar \& Managi, 2009).

Second, earlier literature on environmental management focuses mainly on manufacturing sector because of its visible environmental impacts (Hoffman et al., 2012; Zhu et al., 2013; Kube et al., 2019). Service sector has attracted much less attention. Services might have low environmental impact at point of generation but the direct and indirect environmental effects of their supply chain in form of energy usage, carbon emissions and waste generation merit further investigation (Gil et al., 2001; Rosenblum et al., 2000). In the Indian context, existing studies measuring the impact of environmental practices on firm performance (Gupta and Goldar, 2005; Kumar \& Shetty, 2017; Shashi et al., 2019; Singh et al., 2020; Sudha, 2020) have focused on manufacturing sector while India is predominantly a service driven economy; the service sector accounts for 55.39\% share in country's Gross Value Added (Ministry of Finance, 2020). ${ }^{1}$ Given the energy intensity and economic importance of service sector, it will be worth examining the relationship between the EMPs adopted by the firms in this sector and their financial performance. The present study examines the relationship using a comprehensive dataset of Indian companies covering both, major manufacturing and service sectors.

Third, given the flexibility in choice of environmental practices among firms, we build a comprehensive measure of environmental management through composite variables rather than using a single standard practice like ISO 14001 (Anton et al., 2004; Kumar \& Shetty, 2018). Although previous empirical studies on environmental-financial linkage have found contradictory results, many of these studies suffer from model misspecification and/or limited data (McWilliams et al., 1999; Elsayed \& Paton, 2005; Lin et al., 2019). In addition to controlling firm heterogeneity using longitudinal data, we also address endogeneity in environmental-financial relationship using dynamic panel data model (Elsayed \& Paton, 2005; Endo, 2019). Dynamic panel data analysis controls for endogeneity and dynamics in environmental-financial performance relationship. This study uses generalised method of moments (GMM) to correct for endogeneity in firm's environmental and financial relationship.

To examine environmental-financial link, we use both accounting based measures (Return on Assets and Return on Equity) and market valuation based measures (Tobin $Q^{2}$, Market to Book Value Ratio and Excess Valuation to sales ratio ${ }^{3}$ ). Accounting based measures of performance are based on past data and give a short-term perspective

\footnotetext{
${ }^{1}$ Gross Value Added (GVA) is the rupee value of the amount of goods and services produced in an economy after deducting the cost of inputs and raw materials.

${ }^{2}$ Lindenberg and Ross (1981) define Tobin's $q$ as the ratio of the firm market value to the replacement cost of its assets.

${ }^{3} \mathrm{MBVR}$ is the ratio of the product of the number of equity shares and the closing price of the share on the last day of the financial year to the book value of equity and reserves while EV/S is defined as the excess of market value of firm over book value of assets normalized by sales.
} 
of financial performance. On the other hand, valuation based measures incorporate all relevant market and non-market information into firm valuation to give a long-term perspective of financial performance. To the best of our knowledge, no study has previously investigated the financial impact of environmental management system using static and dynamic panel data regressions while accounting for endogeneity concerns, specifically in the Indian or a developing country context.

Empirical results show a positive impact of environmental management on firm profitability and market valuation. Investors expect that cost of implementing EMPs to improve environmental performance will be offset in the coming years in the form of lower regulatory penalties, higher efficiency in operations and increased goodwill. Therefore, while immediate impact of EMPs adoption on firm profitability and valuation may be insignificant, in the long run green firms are compensated by market in terms of improved profits and higher valuation. This insight is useful in appreciating financial implications of corporate environmentalism for policy makers and corporations.

The remainder of this paper is organized as follows: Section 2 reviews the relevant literature. Section 3 describes the conceptual framework and constructs the hypotheses to be tested in the study. Section 4 covers description of data and Section 5 discusses the econometric estimation methods. The results are presented and discussed in section 6. This paper closes in section 7 with some concluding remarks.

\section{Related Literature}

The relationship between environmental management and firm performance remains a perplexing issue in the literature. Porter's 'win-win' argument states that improved environmental performance backed by properly designed environmental policy leads to enhanced economic benefits due to cost reduction and increased sales (Porter, 1991; Porter \& Van der Linde, 1995). Although this hypothesis is intuitively attractive, empirical studies measuring the impact of environmental management on firm performance are inconclusive. Sinkin et al. (2008) examined the relationship between eco-efficient business strategies and firm's value in American context and found that improved environmental efficiency resulted in better financial performance. Fujii et al. (2012) studied the relationship between environmental performance and economic performance in Japanese manufacturing sector. The results show a positive impact of environmental performance as measured by $\mathrm{CO}_{2}$ emissions on firms overall economic performance and profitability. Similar results have been reported by other studies (Dowell et al., 2000; King \& Lenox, 2001; Konar \& Cohen, 2001; Melnyk et al., 2003; Wagner \& Schaltegger, 2004; Hourneaux et al., 2014; Lucas \& Noordewier, 2016).

On the contrary, Friedman (1970) argued that any environmental expenditure is against the interest of shareholders and results in deterioration of firm performance and value (Jaggi \& Freedman, 1992). Walley and Whitehead (1994) state that environmental management is a costly affair because considerable research expenditure has to be incurred to imbibe green processes and produce green products. Hassel et al. (2005) examined the impact of adopting green management strategies on stock returns and found a negative relation between the two. The results show that investors view 
environmental activities as being carried at the cost of future profits of firm (Thornton, Kagan \& Gunningham, 2003; Sariannidis et al., 2013; Chen et al., 2014).

Furthermore, some studies have not found any linkage between environmental and financial performance. Cohen et al. (1997) study the environmental performance of Standard and Poor's 500 companies and find that neither the 'green companies' are rewarded nor penalized for their environmental efforts. Duque et al. (2020) study the impact of green innovation on financial performance in emerging markets multinationals from Latin America using panel data from 86 listed firms. They fail to establish a link between green practices and financial performance of a firm. Similar results have been reported by Iraldo et al. (2009) and Böhringer et al. (2012). Although the dominant view is that an improved environmental performance enhances financial strength of a firm, the evidence till date remains inconclusive.

This paper revisits environmental-financial performance premise to analyse the impacts of EMPs adoption. Indian industry (both manufacturing and services) is highly pollution intensive despite extensive environmental regulations due to limited institutional capacity, lack of trained personnel and inadequate data on emissions. Hence, there is a need to examine the impact of environmental management on financial performance in a developing country like India.

Existing studies have majorly used pooled or cross sectional data (Henriques \& Sadorsky, 1996; Konar \& Cohen, 2001; Boiral et al., 2012; Chiarini, 2017). In the presence of firm heterogeneity, inferences based on cross-sectional data are likely to be biased. Panel data analysis controls for firm-specific and period-specific heterogeneity. However, limited studies have used panel data to study environment-financial performance linkage. King \& Lenox (2001) conduct a longitudinal study of American manufacturing firms and find that waste prevention leads to improvement in firm performance as measured by $R O A$ and Tobin $Q$. In their study on 89 multinational corporations for the period 1994-97, Dowell et al. (2000) find that adherence to strict environmental regulations improves financial performance of firms. Rassier \& Earnhart (2009) employ panel data analysis to examine the effect of Clean Water Act on financial performance of publically owned firms in chemical manufacturing industries. Empirical results show a negative impact of clean water regulation on future financial performance as measured by Tobin $Q$. We use eleven year panel data from 459 firms belonging to twenty one Indian industries to study impact of corporate environmentalism on financial performance.

Moreover, majority of existing studies have considered EMP-financial performance linkage in one direction i.e. adoption of better environmental practices improves firm performance. The considerations of dynamics and reverse causality are relevant in relationship between environmental management and financial performance. Hart \& Ahuja (1996) state that delay in achieving financial gains from environmental initiatives can be attributed to increased short term costs due to restructuring in the organisation. In a study of 127 companies listed on S\&P 500, empirical results suggested that it takes one to two years for environmental performance to positively impact firm performance as measured by ROS, ROA and ROE. The financial benefits were more for 'high polluters' than 'low polluting' firms across all models. Guenster et al. (2008) also suggests that market valuation of firm's environmental performance may be time variant i.e. market incorporates environmental information with a drift. 
Dynamic panel data analysis controls for endogeneity and dynamics in environmentalfinancial performance relationship. We came across multiple studies using dynamic panel analysis to test environment Kuznets curve (EKC hypothesis) across countries but studies at firm level are limited (Coondoo \& Dinda, 2002; Lee et al., 2010; Hua \& Boateng, 2015). Elsayed \& Paton (2005) conduct a static and dynamic panel data analysis to study the impact of environmental performance on financial performance in 227 UK firms belonging to 26 sectors during 1994-2000. Empirical results reveal a positive impact of environmental performance on $R O A$ in chemical and telecommunication and a negative impact in textiles, clothing, metals and automobiles. Endo (2019) found a positive relation between environmental performance and firm value in Japanese manufacturing sector using static panel regression. However, with introduction of dynamic panel data models, this relation became insignificant. Controlling for firm-heterogeneity and endogeneity, we employ static panel least squares and dynamic panel GMM estimations to study the impact of EMPs adoption on firm's profitability and valuation in the Indian context.

\section{Conceptual framework and hypotheses construction}

The objective of this paper is to study the impact of environmental management system on financial performance in Indian firms. A conceptual relationship between adoption of EMPs and their financial implications is depicted in Figure1.

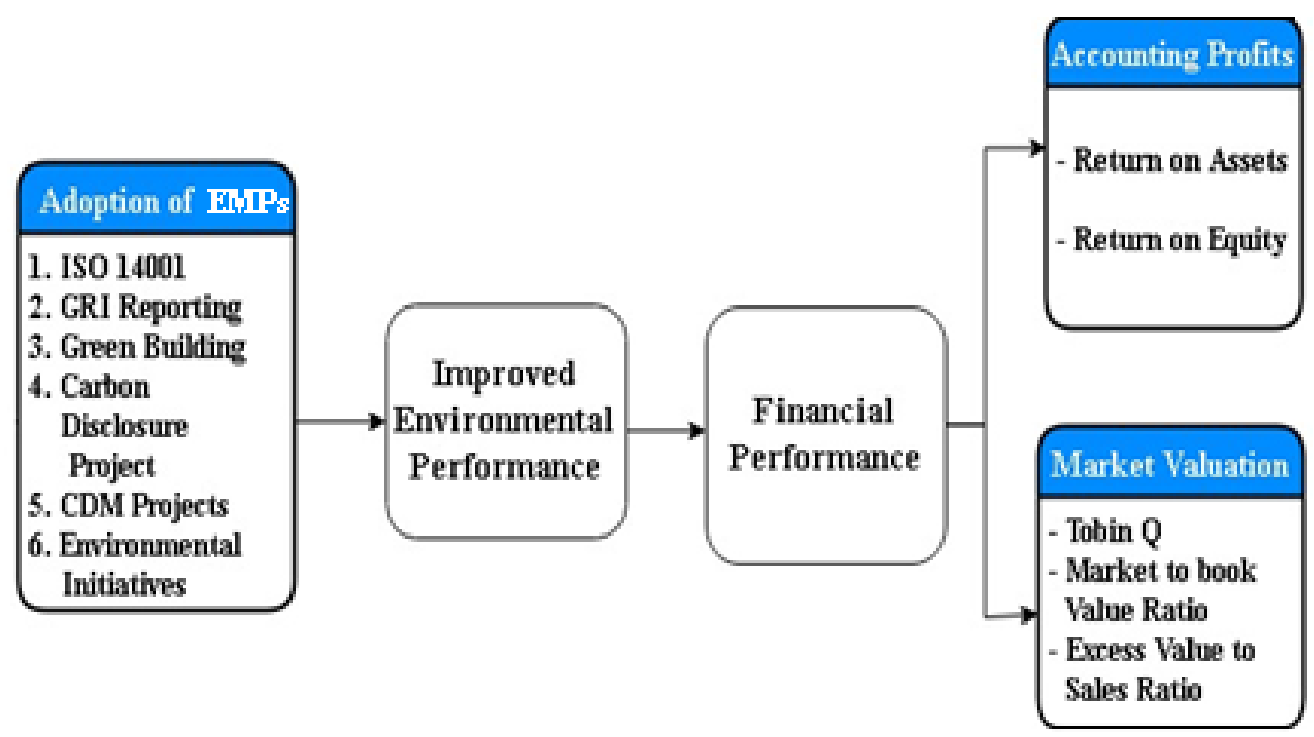

Figure 1: Conceptual Framework

Firms can gain sustainable competitive advantage by assuming environmental responsibility of their operations. Pollution is a waste of input and reflects firm's inefficiency in product design, choice of input and manufacturing process (Nehrt, 1996). A proactive environmental management strategy is expected to enhance firm performance through process innovation and product differentiation (Porter \& van der Linde, 1995; Reinhardt, 1998; Shashi et al., 2019). 
We study the effect of EMPs on firm performance using accounting and market value based measures. Firms adopt voluntary environmental measures in response to external factors like pressure from customers, investors and regulators, and internal capabilities like innovation and research and development (R\&D). It is hypothesized that firms with efficient environmental management exhibit improved profitability due to reduced wastages, reduced cost of inputs, less public and regulatory pressure and improved competitiveness with increased product value (Arora \& Cason, 1995). Therefore, we hypothesize that:

\section{Hypothesis 1: Adoption of EMPs has a positive impact on firm profitability}

To test above hypothesis we use commonly used measures of profitability based on accounting measures of firm performance: Return on Assets (ROA) and Return on Equity $(R O E)$. Accounting measures of firm performance are easy to calculate and give a short-term perspective of firm performance (Hart \& Ahuja, 1996; Jaggi \& Freedman, 1992; ). ROA measures the profit a firm generates with the money invested by its shareholders. Though ROA measures a firm's financial strength, it fails to indicate whether firm is having excessive debt or using debt to drive returns. ROE overcomes this shortcoming by measuring how efficiently a firm is using its shareholder's funds to generate profits. $R O E$ indicates firm's ability to maximise return to its shareholders based on their investment in the firm (Alexander \& Nobes, 2001; Stickney et al., 2007). Together, $R O A$ and $R O E$ present a clear picture of management's effectiveness.

Though accounting measures explain how firm earnings respond to managerial decisions, they fail to give a forecast of its future expectations. Accounting measures are based on past performance of firm and use historical costs of assets. Further they ignore value of intangible assets and inflationary effects. As a result their predictive value is quite low (Cochrane\& Wood, 1984; Keats \& Hitt, 1988).

On the other hand, market valuation based measures of performance are forwardlooking and measure firm's ability to earn profits in future. They incorporate all relevant information and thus, unlike accounting measures, they are not limited to a single effect of firm performance (Lubatkin \& Shrieves, 1986). Advanced environmental practices can enable a firm to achieve organizational efficiency thereby leading to improved perception of firm's ability to generate future economic earnings with lower business risks (Dowell et al., 2000; King \& Lenox, 2002; Konar \& Cohen, 2001). Gregory \& Whittaker (2013) recommend that market value, accounting earnings and book value should be considered simultaneously in investigating the financial impact of environmental management. Therefore, it is hypothesized that firms which adopt environmental management practices send positive signals to the market resulting in higher firm valuation.

Hypothesis 2: Adoption of EMPs has a positive impact on the market valuation of a firm.

A firm's market value is generally measured using Tobin $Q$. In the present study, we use two additional measures of firm valuation; market to book value ratio (MBVR) and excess valuation to sales $(E V / S)$ ratio. 
Tobin $Q$ is defined as the ratio of firm market value to its replacement cost of assets. Estimation of firm valuation, using Tobin $Q$, is problematic in a developing country like India with under-developed capital market due to non-availability of data on market value of debt and replacement costs of assets (Sarkar \& Sarkar, 2012). Tobin $Q$ suffers from omitted variable bias. Consequently, we use $M B V R$ as an alternative measure of firm valuation. Unlike Tobin $Q$, no computational adjustments are required when we use $M B V R$.

Excess valuation to sales ratio, another measure of market valuation, is a measure of long-term wealth creation potential of firm. This ratio helps to measure value of premium or discount accorded by market to firm based on evaluation of future prospects of the firm. Spread between market value and book value of firm is a measure of its perceived ability to return to its stockholders a future amount in excess of their expected return (Connolly \& Hirschey, 1986; Shalit \& Sankar, 1977). EV/S controls for size and leverage variation across firms (Errunza \& Senbet, 1981; Galbraith \& Stiles, 2008; Thomadakis, 1977).

\section{Description of Data}

Sample: This study is based on firm level data from leading Indian industries. To trace the impact of manufacturing sector on environment, we first picked the CPCB list of 'most polluting' Indian industries. CPCB is a statutory body constituted in 1974 under the Water (Prevention and Control of Pollution) Act. It is the chief advisor to Government of India on matters related to air and water pollution. In 1991, CPCB identified 17 categories of highly polluting industries in India. ${ }^{4}$ CPCB along with State Pollution Control Boards (SPCBs) keeps a check on pollution control facilities and compliance in these industries.

To build our sample, we first choose all the major manufacturing and service sector industries in India using CMIE Prowess database. The chosen manufacturing industries include the 17 polluting industries. Next we calculate their average energy intensity. Energy intensity of an industry has been calculated as ratio of energy cost ${ }^{5}$ to net sales (Goldar, 2010; Sahu \& Narayanan, 2011). The average energy intensity (in Rs crores) for the 25 industries is given in Appendix Table A1. There were some industries which had high energy intensity but were dropped due to small industry size. The small size of the industry might limit their aggregate environmental effect.

Next we pick all large listed enterprises from each of the industry. ${ }^{6}$ Top industry performers are chosen as they are more likely to use a wider variety of environmental practices vis-a-vis smaller firms. Although selection of large and publically listed firms limits the extent to which we can generalize our findings to smaller firms, there is in fact substantial variation in sample, both within sector and over time. The firms differ

\footnotetext{
${ }^{4} \mathrm{CPCB}$ list includes aluminium smelter, caustic soda, cement, copper smelter, distilleries, dyes and dye intermediates, fertilizers, integrated iron and steel, tanneries, pesticides, petrochemicals, drugs, pharmaceuticals, pulp and paper, oil refineries, sugar, thermal power plants and zinc smelter.

${ }^{5}$ Energy cost is defined as expenditure on power and fuel.

${ }^{6}$ In May, 2020 the definition of Micro and Medium enterprises was revised by the Finance Ministry. Large enterprises are units with turnover exceeding 250 crore and asset investment above 20 crore.
} 
in size, products, processes and industries. A final database of 459 large listed Indian companies is created. ${ }^{7}$

Time Period: In order to understand how the adoption of EMPs has impacted firm performance, we form a panel database covering an eleven year period from 2008-0910 to 2018-19. The data collected covers publically traded firms in both manufacturing and service sectors.

Sources of Data: Data on firm level environmental practices has been extracted from sustainability and business responsibility report of companies. Data on independent variables is extracted from CMIE Prowess database, audited annual reports and business responsibility reports of the companies. Use of publically available database removes subjectivity and gives a fair view of current environmental state in the sample companies.

The study aims to measure the impact of EMPs adopted by a firm on its financial performance. The variable EMP is the sum of various environmental practices adopted by a firm. It is measured through six environmental practices which cover the pro-active orientation of a firm towards environmental concerns. The environmental practices include:

I. ISO 14001 certification: This is an internationally recognized EMS standard released by International Organization for Standardization (ISO). It provides a comprehensive framework that an organization has to follow to frame an effective environmental management system. In fact, ISO 14001 is the most popular and widely used indicator of EMS of an organization.

II. GRI certified sustainability reports: Global Reporting Initiative (GRI) is an independent organization releases the standards on sustainability reporting and disclosure. It helps organizations understand and communicate impact of their business on environment, climate change, human rights etc.

III. BEE/LEED certified green buildings: A green building is one whose construction and operation does not disrupt air, land, plantation and energy. It promotes a healthier and greener environment. The construction and subsequent usage of green buildings exhibit environmental commitment of a company.

IV. Carbon Disclosure Project: CDP is a global disclosure system that enables companies to measure and manage their environmental impacts. Voluntary participation of a firm in CDP is a way of meaningful steps taken by them to address their environmental impacts.

V. Clean Development Mechanism (CDM) projects: CDM is a voluntary emission reduction project being operated by a company. This commitment is made under Kyoto Protocol to implement an emission reduction project in a developing country. It is an environmental investment and credit scheme, which provides the participating company with a standardized emission offset instrument, Carbon Emission Reductions (CERs).

VI. Environmental expenditure: This variable covers the entire gamut of pollution reduction and pollution control activities undertaken by firms in addition to above listed practices. It includes efforts made to preserve water, recycle and treat waste, use clean energy, provide environmental training to staff and hire

\footnotetext{
${ }^{7}$ The words ‘company’, ‘enterprise’ and 'firm’ are used interchangeably throughout the study.
} 
consultants. A company incurs environmental expenditure in some of these areas.

Since the firms have flexibility in their choice of environmental practices, comprehensiveness of EMPs varies across firms. Each of these environmental practices is represented by a dummy variable as described in Table 1. Among the six environmental practices, ISO 14001 accreditation with mean value 0.751 is most popular practice among large Indian firms.

Table 2 presents the summary of variables used in the study. This table gives mean and standard deviation of all dependent, explanatory and control variables used in study. Large listed firms on average adopt 2.56 EMPs with standard deviation of 1.95 implying large variability in environmental management practise among firms. High standard deviation of other variables reiterates the aforesaid statement about substantial variation in our sample companies. Correlation matrix of variables used in study is presented in Table 3. The correlation among variables is relatively low signifying absence of collinearity among independent variables.

\section{Econometric Estimation}

We aim to measure the impact of environmental management on firm's financial performance. Adoption of environmental management practices involves detailed assessment of products, processes and other corporate activities for their possible environmental impacts. Improvement in operational efficiency leads to improvement in regulatory compliance and reduction in fines, costs, wastages and pollutants. This improves firm's profitability. EMP adoption also leads to increased goodwill by building a positive image of firm in market. These positive signals by firm lead to an improvement in its market valuation. Voluntary environmental management is expected to impact the current and long term financial performance of a firm differently. While a large proportion of expenditure on EMPs is likely to be incurred immediately after its adoption, financial benefits are realised in the long term (Khanna \& Damon, 1999; Guenster et al., 2008). Accordingly, the regression equation is:

$R O A_{i t}$ or $R O E_{i t}=\beta_{0}+\beta_{1} E M P_{i t}+\beta_{2} F V_{i t}+\varepsilon_{i t}$

where $R O A$ is the return on assets and $R O E$ is the return on equity; EMP is sum of environmental practices; FV stands for firm specific variables. Subscripts i indicates firm and subscript $\mathrm{t}$ is for the time period; and $\varepsilon$ is random error term.

Market valuation of a firm (MV) is attributable to value generated by its tangible $\left(\mathrm{V}_{\mathrm{TA}}\right)$ and intangible assets $\left(\mathrm{V}_{\mathrm{IA}}\right)$.

$M V=V_{T A}+V_{I A}$

We use three market value based measures of firm's financial performance: Tobin $Q$, $M B V R$ and $E V / S$. To test the proposed hypothesis using Tobin $Q$, we use a regression model following Konar \& Cohen (2001) which studies impact of various factors on the intangible asset value of firm. On other hand, EV/S measures value of premium or 
discount accorded by market to firm based on evaluation of future prospects of the firm (Errunza \& Senbet, 1981; Galbraith \& Stiles, 2008; Thomadakis, 1977).

$M V_{i t}=\beta_{0}+\beta_{1} E M P_{i t}+\beta_{2} F V_{i t}+\varepsilon_{i t}$

where MV stands for Tobin Q or EV/S, EMP is sum of environmental practices; FV stands for firm specific variables. Subscripts i indicates firm and subscript $t$ is for the time period; and $\varepsilon$ is random error term.

In developing countries, like India, use of Tobin $Q$ as a measure of market valuation may be problematic since capital markets are underdeveloped and data on market value of debt and replacement cost of assets is generally missing (Sarkar \& Sarkar, 2012). Therefore, we use $M B V R$ as an alternative measure of firm valuation. We consider market value of equity as a function of its book value, financial performance and environmental performance (Gregory \& Whittaker, 2013; Hassel et al., 2005; Kumar \& Shetty, 2017; Ohlson, 1995). We consider,

$\frac{M V_{i t}}{B V_{i t}}=\beta_{0}+\beta_{1} \frac{1}{B V_{i t}}+\beta_{2} \frac{N I_{i t}}{B V_{i t}}+\beta_{3} E M P_{i t}+\beta_{4} F V_{i t}+\varepsilon_{i t}$

where $M V$ is market value of equity, $B V$ is book value, $N I$ is net income, $E M P$ which is sum of environmental management practices in period i in firm $t$ and FV represent firm specific non-environmental variables in period t by firm $\mathrm{i}$.

To overcome model misspecification, we include a number of control variables that can impact environment-financial performance relationship (Alexopoulos et al., 2018). Firm specific variables used in this study are R\&D intensity, advertising intensity, asset age, multinational status, sales growth, size and age of firm. Firm size is a relevant variable due to possible existence of economies of scale in environmentally oriented investments. The smaller firms may not be as socially responsible as larger firms are (Makni et al., 2008; Waddock \& Graves, 1997). Larger firms receive higher public attention, possess more slack resources, experience economies of scale which in turn, 'encourages' them to have better environmental performance (Fombrun \& Shanley, 1990; Clarkson et al., 2011). Sales-asset ratio has been used as a measure of firm size. Next we include R\&D intensity (research and development expenditure divided by sales) and advertising intensity (advertising expenditure divided by sales). R\&D intensity and advertising intensity proxy firm innovation and omitting these variables can lead to misleading results. While R\&D expenditure might help to add environment friendly attributes to product offerings, advertising can be used to raise consumer awareness about green products. This helps the firm to differentiate its product offering from competitors (McWilliams \& Siegel, 2000). We use debt-equity ratio as a measure of firm's risk (Waddock \& Graves, 1997). A firm with high debt-equity ratio is expected to have lower market valuation (Shetty \& Kumar, 2017). Next variable used is Assetage which is calculated as ratio of net fixed assets to total assets. ${ }^{8}$ Firms with older equipment and technology are likely to be less efficient and less profitable (Konar \& Cohen, 2001). Firm age (years since incorporation) has also been included as a control variable. Age represents the lifecycle stage of the firm which has an impact on

\footnotetext{
${ }^{8}$ The age of a firm's assets is proxied by dividing the value of the property, plant, and equipment of firm (net of accumulated depreciation) by its gross value. This gives us a $0-1$ scale for the age of a firm's assets, with a firm closer to 1 having newer assets.
} 
profitability (Hanks et al., 1993). MNC status enables access to better technology, more finances and hence is assumed to lead to better financial performance (Shetty \& Kumar, 2017). Sales Growth (SG) is a measure of future growth opportunities and is expected to have a positive impact on firm performance (Konar \& Cohen, 2001).

Two econometric methods are used to gauge the relationship between EMPs adoption and firm performance. We first use static regression to test hypothesis 1 and hypothesis 2 controlling for firm specific and period specific unobserved heterogeneity, and then use dynamic regression model to control for potential biases associated with endogeneity.

Under static panel least square estimation we use both random and fixed effects model. Random effects model assumes individual specific effect to be a random variable uncorrelated with all explanatory variables. On the other hand, fixed effects model allows individual specific effects to be correlated with explanatory variables. Hausman test is used to check the consistency of random effects vis-a-vis fixed effects model (Wooldridge, 2010). Hausman test statistics reject null hypothesis and fixed effects model is selected (Tables 4 and 5).

Besides heterogeneity, endogeneity of explanatory variables in regression model may affect our empirical estimates. Dynamic panel regression is an effective way of controlling endogeneity. A simple way of allowing dynamic effects is inclusion of lagged dependent variable in regression equation. However, introduction of lagged dependent variable violates strict exogeneity and can lead to inconsistent standard estimators. Following Arellano and Bond (1991), we control for potential endogeneity of all explanatory variables using GMM estimation. This approach works well in small time periods with large individual units. Arellano-Bond estimator controls for potential endogeneity by setting up a GMM estimation to deploy additional instruments obtained by orthogonality conditions existing between lagged value of dependent variable and differenced disturbances (Baum et al., 2003). Instrumental variables are all the righthand side variables lagged twice or more. The efficiency of GMM estimation is dependent on effectiveness of instruments and non-correlation between error terms. Consequently, we use Sargan test based on full Arellano and Bond (1991) instrument set to test the over-identifying conditions and Arellano-Bond test to check first- and second-order autocorrelation in the first differenced errors. Sargan test statistics indicates the appropriateness of instruments used in our dynamic regression model. $\mathrm{AR}(1)$ and $\mathrm{AR}(2)$ values suggest that errors are not serially correlated.

\section{Empirical Results}

Regression results for hypothesis 1, measuring impact of EMPs on firm profitability using static fixed effects and dynamic panel regression are presented in Table 4. Specifications 1 and 2 show impact on $R O A$ while specifications 3 and 4 show impact on $R O E$. We find no statistically significant impact of EMP on ROA and ROE under static regression. This finding is consistent with the findings of Cohen et al. (1997). Under dynamic regression, environmental management shows a significant positive 
impact on $R O E$ in current year $(E M P)$ along with one year $\left(E M P_{t-1)}\right.$ and two year positive lag $\left(E M P_{\mathrm{t}-2)}\right.$. A similar result is obtained by Angelia and Suryaningsih (2015). However, $R O A$ improves one year post EMP implementation, i.e., adoption of an additional environmental practice in time period $t$ improves firm's profitability in $t+1$ and $\mathrm{t}+2$ time period. In the initial years of EMPs implementation, a firm undergoes many structural changes which involve financial costs. Subsequently, it is able to optimise resource usage by adoption of efficient and lean production practices. This leads to cost savings and reduction in wastages, thereby enhancing its long run profitability (Cochrane \& Wood, 1984; Khanna \& Damon, 1999). Under dynamic analysis, $R O A$ and $R O E$ improve by $0.79 \%$ and $0.33 \%$ respectively in $\mathrm{t}+1$ while by $1.27 \%$ and $0.42 \%$ respectively in $\mathrm{t}+2$ time period. A favourable impact of EMP on firm profitability supports past findings (Hart \& Ahuja, 1996; Alexopoulos et al., 2018).

We also find a statistically significant and positive impact of advertising intensity on firm profitability and valuation. Increase in advertising intensity by one unit, improves $R O A$ by $2.34 \%$ and $R O E$ by $0.70 \%$ under static regression. Under dynamic analysis, increase in advertising intensity by one unit improves $R O A$ by $0.14 \%$ and $R O E$ by $0.027 \%$. Advertising enables product differentiation leading to customer loyalty and building of brand value. Increased brand value creates potential for higher selling prices that results in higher revenue and improved profits (Hirschey \& Weygandt, 1985). Sales/asset ratio has a positive and statistically significant coefficient across all specifications. One unit increase in sales/asset ratio improves $R O A$ by $1.99 \%$ and $R O E$ by $0.04 \%$ under static regression. Under dynamic analysis, increase in sales/asset ratio by one unit improves $R O A$ by $1.89 \%$ and $R O E$ by $0.04 \%$. Bigger firms with more resources at their disposal exhibit higher market valuation and profitability (Fombrun \& Shanley, 1990; Waddock \& Graves, 1997; Clarkson et al., 2011; Alexopoulos et al., 2018). We find a statistically significant negative relationship between Assetage and $R O A$ and ROE. This shows that firms with older equipment and obsolete technology are less efficient and less profitable. This finding concurs with the finding of Konar \& Cohen (2001). The impact of MNC status on firm profitability is positive and significant across all specifications. Multinational Corporations enjoy benefits of internationalisation with economies of scale and scope. They are able to reduce costs and improve productivity leading to improved financial performance (Helpman et al., 2004). Leverage has a statistically significant positive impact on ROE. Usage of debt has a negative impact on revenue as more money is spent on servicing debt but if return on investment is higher than interest cost, use of debt leads to exponential increase in firms' profitability (Abor, 2005; Robb and Robinson, 2009). We obtain similar results for a large sample of 1439 large Indian enterprises (listed and unlisted) implying the robustness of the results (Appendix Table 2).

Regression results showing the impact of EMP adoption on firm valuation for hypothesis 2 are presented in Table 5 . Under static regression, we do not find any impact of environmental management on concurrent market valuation. It is only in the second year that we find significant impact of EMPs on EV/S. Under dynamic regression, we find a positive and statistically significant impact of EMP on concurrent firm Tobin Q and EV/S. MBVR improves one year post EMP adoption while market valuation improves in $\mathrm{t}+2$ time period for all measures of market valuation. Firm's Tobin $Q$ improves by 1.03 units and 0.65 units in period $t$ and $t+2$ respectively. Results are consistent with previous studies showing positive impact of corporate environmentalism on Tobin Q (Dowell et al., 2000; Okada \& Iwata, 2011; Wagner, 
2010). With one additional environmental practice, dynamic EV/S improves by 52.18 units concurrently and by 60 units in $\mathrm{t}+2$ respectively. Positive and significant impact of EMP on EV/S shows that investors are attracted to environmentally pro-active firms because of potential of long-term wealth creation and above average returns (Cochran and Wood, 1984; Khanna \& Damon; 1999). Dynamic MBVR increases by 0.41 units in period $\mathrm{t}$ and by 2.18 units in $\mathrm{t}+2$ respectively. Firms adopting higher number of environmental practices are considered less risky compared to their peers and are thus a preferred investment alternative (Gregory \& Whittaker, 2013; Hassel et al., 2005; Kumar \& Shetty, 2017). Guenster et al. (2008) suggests that though market assigns a value-relevance to firm's environmental management, market valuation of environmental performance may be time variant i.e. market incorporates environmental information with a drift.

Results suggest that firm size has a positive impact on firm valuation. Firms with slack resources available for environmental investments take advantage of investment opportunities available in market to enhance their profitability and valuation (Makni et al., 2008; Waddock \& Graves, 1997; Wagner, 2010; Alexopoulos et al., 2018). Increase in advertising intensity improves firm's financial performance under static and dynamic panel analysis. One unit increase in advertising intensity leads to an increase of 13.56 units in Tobin Q, 2.29 units in EV/S and 2.41 units in MBVR under static analysis and increase of 35.98 units in Tobin Q, 5.68 units in EV/S and 3.12 units in MBVR under dynamic analysis.

Advertising by green firms sends out a positive signal to market about its future growth potential. Customers assign a higher value to environmentally pro-active firms as compared to their peers (Konar \& Cohen, 2001; McWilliams \& Siegel, 2000). Under dynamic regression, we find a positive impact of MNC and negative impact of Assetage on firm valuation respectively. MNCs implement processes that enable more efficient utilisation of resources and ability to relocate activities to reduce costs (Helpman et al., 2004). Pantzalis (2001) found that MNCs operating in developing economies witness higher market valuation. Ageing asset stock of a firm makes it less efficient thereby, reducing profitability and market valuation (Konar and Cohen, 2001).

Dynamic panel estimates suggest a joint positive and significant impact of $E M P, E M P_{\mathrm{t}}$ 1 and $E M P_{\mathrm{t}-2}$ adoption on firm's market valuation and profitability (Dowell et al., 2000; King \& Lenox, 2001; Makni et al., 2008). Environment friendly products and processes enhance firm profitability either through cost savings or revenue gains. Investment in $E M P$ s reduces costs through efficient utilisation of existing resources with lower wastages and environmental liabilities. This improves firms' profitability and they are valued highly by market (Sinkin et al., 2008; Mishra \& Suar, 2010). Customer preference for products from environmentally pro-active companies increases their revenue (Delmas \& Toffel, 2004; Henriques \& Sadorsky, 1996; Rivera, 2000). Adoption of EMPs leads to improved investor perception of firm's ability to generate future economic earnings with lower business risks resulting in higher market valuation of the firms (Dowell et al., 2000; Klassen \& McLaughlin, 1996; Konar \& Cohen, 2001).

Growing firms with increased sales and ability to spend more on advertising are able to improve their financial performance both in short run and long run. Such firms are able to communicate their environmental initiatives to public through media and annual reports. They succeed in differentiating themselves from competitors and convince 
customers about their superior product offering. Improvement in firm's environmental performance adds to its goodwill and reputation. These voluntary environmental initiatives are valued by market and hence in the long run, environmentally responsible firms exhibit higher profitability and market valuation. The results also show that big firms are more likely to adopt voluntary environment practices. This may be due to 'increased public scrutiny' and economies of scale enjoyed by bigger firms (Henriques \& Sadorsky, 1996; McWilliams \& Siegel, 2001; Alexopoulos et al., 2018).

Though static panel data model controls for firm specific effects, the potential endogeneity of explanatory variables still exists. Controlling for reverse causality and endogeneity under dynamic panel analysis strengthens our results with significant and positive impact of EMPs adoption on profitability and valuation measures. Thus, allowing for dynamics in environmental-financial performance relationship is important as static regression estimates may be biased downwards (Elsayed and Paton, 2005; Endo, 2019). Firms that choose to improve their environmental performance over time experience improved financial performance in subsequent periods.

\section{Conclusion}

This study sought to establish empirical evidence on the relationship between corporate environmental management and firm performance in a developing country like India. We use a panel data of 459 Indian companies for a period of eleven years. Use of static panel analysis controls for firm heterogeneity while dynamic panel GMM estimation controls for endogeneity and reverse causality in environment- financial performance relationship along with heterogeneity.

The study presents new evidence on whether 'it pays to be green' using five alternative measures of firm performance: ROA, ROE, Tobin Q, MBVR and EV/S. Empirical results show that environmentally pro-active large firms experience improvements in profitability and valuation. These firms implement a number of green practices such as ISO14001 accreditation, sustainability reporting, participating in CDP, adoption of CDM projects and use of green buildings. Such firms are able to convince customers of their superior product offering and differentiate themselves from market competitors. Corporate environmentalism is valued by market and in the long run such firms exhibit higher profitability and valuation.

The results of this study can be used by firms and policy makers to understand the financial implications of environmental management. Firstly, policy makers need to acknowledge that in a developing country like India which is characterised by low compliance and ineffective surveillance, the most effective tool of stirring business firms towards environmental responsibility is by making them appreciate 'costs and benefits' of environmental management.. The policy makers should understand the coherence of the industry policy and environmental policy. The two are inherently intertwined and should be coordinated in their implementation as industrial upgrading can foster greener growth, and green growth can help in industrial upgrading in turn. Implementation of technologically superior processes can lead to cost-effective solutions to environmental problems without undermining economic output. Thirdly, corporate directors need to understand that though costly in short run, EMPs can be nurtured as a rare and valuable resource that can be harnessed to give the firm a 
sustainable competitive advantage over its competitors. Large Indian enterprises are continuously striving for improvement in performance by adopting varied green practices. This can show the way to small and medium industry players. The government should acknowledge that the key to improving productivity, environmental compliance and maintaining the competitiveness of the Indian industries will increasingly rely on innovation and entrepreneurship. More and more skill development programs and Industrial Training Institutes should be promoted.

The study is not free of limitations. This study is based on secondary data. Supplementing it with primary data can provide a deeper insight into motivations and barriers to environmental management at firm level. Lack of data on environmental performance of Indian firms limits our ability to study the effectiveness of the environmental practices adopted. Studying the variation in financial impact of EMPs across developing countries can be an interesting area of future. 


\section{REFERENCES}

Abor, J. 2005. The effect of capital structure on profitability: an empirical analysis of listed firms in Ghana. Journal of Risk Finance, 6(5), 16-30.

Alexander, D., \& Nobes, C. 2001. Financial Accounting: An International Introduction. Harlow: Financial Times, Prentice Hall.

Alexopoulos, I., Kounetas, K. \& Tzelepis, D. 2018. Environmental and Financial Performance. Is there a win-win or a win-loss situation? Evidence from the Greek

Manufacturing. Journal of Cleaner Production, doi: 10.1016/j.jclepro.2018.06.302

Angelia, D. and Suryaningsih. 2015. The Effect of Environmental Performance And Corporate Social Responsibility Disclosure Towards Financial Performance. Procedia - Social and Behavioral Sciences, 211, 348 - 355.

Anton, W.R.Q., Deltas, G., \& Khanna, M. 2004. Incentives for environmental selfregulation and implications for environmental performance. Journal of Environmental Economics and Management, 48(1), 632-654.

Arellano, M., \& Bond, S. 1991. Some test of specification for panel data: Monte Carlo evidence and an application to employment equation. The Review of Economic Studies, 58 (2), 277-297.

Arora, S., \& Cason, T.N. 1995. An experiment in voluntary environmental regulation: Participation in EPA's 33/50 program. Journal of Environmental Economics and Management, 28(3), 271-286.

Baum, C.F., Schaffer, M.E., \& Stillman, S. 2003. Instrumental variables and GMM: Estimation and testing. The Stata Journal.

Böhringer, C., Moslener, U., Oberndorfer, U. \& Ziegler, A. 2012. Clean and productive? Empirical evidence from the German manufacturing industry. Research Policy, 41, 442-451.

Boiral, O., Henri, J.F., Talbot, D. 2012. Modeling the Impacts of Corporate Commitment on Climate Change. Business Strategy and Environment, 21, 495516.

Capon, N., Fitzsimons, G., \& Prince, R. 1996. An individual level analysis of the mutual fund investment decision. Journal of Financial Services Research, 10(1), 59-82.

Carbon Disclosure Project Worldwide. 2017. The Carbon Majors Database- CDP Carbon Majors Report 2017. CDP, London.

Central Pollution Control Board. 2001. Parivesh- A newsletter from ENVIS centreCPCB. $\quad$ http://cpcbenvis.nic.in/cpcb_newsletter/Polluting\%20Industries.pdf Accessed on 8 June 2015.

Chiarini, A. 2017. Setting Strategies outside a Typical Environmental Perspective Using ISO 14001 Certification. Business Strategy and Environment, 26, 844-854.

Clarkson, P.M., Li, Y., Richardson, G.D. \& Vasvari, F.P. 2011. Does it really pay to be green? Determinants and consequences of proactive environmental strategies. Journal of Accounting and Public Policy, 30(2), 122-144.

Cochrane, P.L., \& Wood, R.A. 1984. Corporate social responsibility and financial performance, Academy of Management Journal, 27(1), 42-56.

Cohen, M.A., Fenn, S.A., \& Konar, S. 1997. Environmental and Financial Performance: Are They Related? Nashville TN: Working paper, Vanderbilt University.

Coondoo, D., \& Dinda, S. 2002. Causality between income and emission: a country group-specific econometric analysis. Ecological Economics, 40, 351-367.

Connolly, R.A., \& Hirschey, M. 1984. R and D, Market Structure and Profits: A ValueBased Approach. The Review of Economics and Statistics, 66(4), 682-686. 
Curkovic, S., \& Sroufe, R. 2011. Using ISO 14001 to promote a sustainable supply chain strategy. Business Strategy and the Environment, 20(2), 71-93.

Dasgupta, S., Hong, J.H., Laplante, B., \& Mamingi, N. 2006. Disclosure of environmental violations and stock market in the Republic of Korea. Ecological Economics, 58, 759-777.

Dasgupta, S., Laplante, B., \& Mamingi, N. 2001.Pollution and Capital Markets in Developing Countries. Journal of Environmental Economics and Management, 42(3), 310-345.

Delmas, M.A., \& Toffel, M.W. 2004. Stakeholders and environmental management practices: an institutional framework. Business Strategy and the Environment,13 , 209-222.

Dowell, G., Hart, S.L., \&Yeung, B.2000. Do corporate global environmental standards create or destroy market value. Management Science, 46 (8), 1059-1074.

Duque, E., Caracuel, J., Guerrero-Villegas, J. \& García-Sánchez, E. 2020. Does green innovation affect the financial performance of Multilatinas? The moderating role of ISO 14001 and R\&D investment. Business Strategy and the Environment. 10.1002/bse.2572.

Elsayed, K., \& Paton, D. 2005. The impact of environmental performance on firm performance: static and dynamic panel data evidence. Structural Change and Economic Dynamics, 16(3), 395-412.

Endo, K. 2019. Does the stock market value corporate environmental performance? Some perils of static regression models. Corporate Social Responsibility and Environmental Management, 1-9.

Errunza, V. R., \& Senbet, L. W. 1981. The effects of international operations on the market value of the firm: Theory and evidence. Journal of Finance, 36(2), 401-417.

Ervin, D., Wu, J., Khanna, M., Jones, C. \& Wirkkala,T. 2013. Motivations and Barriers to Corporate Environmental Management. Business Strategy and the Environment,22(6), 390-409.

Fombrun, C., \& Shanley, M. 1990. What's in a Name? Reputation Building and Corporate Strategy.Academy of Management Journal, 33, 233-258.

Friedman, M. 1970. A Theoretical Framework for Monetary Analysis.Journal of Political Economy, 78(2), 193-238.

Fujii, H., Iwata, K., Kaneko, S., \& Managi, S. 2013. Corporate Environmental and Economic Performance of Japanese Manufacturing Firms: Empirical Study for Sustainable Development. Business Strategy and the Environment, 22(3), 187-201

Galbraith, C.S., \& Stiles, C.H. 2008. Market Share, Scale, and Market Value: An Empirical Study of Small Closely Held Manufacturing Firms. Journal of Small Business and Entrepreneurship, 21(4), 435-447.

Gil, M.J.A., Jimenez, J.B., \& Lorente, J.J.C. 2001. An anaysis of environmental management, organizational context and performance of Spanish hotels. Omega,29(6), 457-471.

Goldar, B. 2010. Pro-Market Reforms and Indian Industry: Developments in the Last Two Decades.https://ssrn.com/abstract=1663583. Accessed on 24 January 2019.

Gregory, A., \& Whittaker, J. 2013. Corporate Social Responsibility and Firm Value: Disaggregating the effects on cash flow, risk and growth. Journal of Business Ethics, 116, 1-20.

Guenster, N., Derwall, J., Bauer, R. \& Kodijk, K. 2006. The economic value of corporate eco efficiency. European Financial Management, 17(4),679-704.

Gupta, S., \& Goldar, B. 2005. Do stock markets penalize environment-unfriendly behaviour? Evidence from India. Ecological Economics, 52, 81-95. 
Hanks, S., Watson, C., Hansen, E., \& Chandler, G. 1993. Tightening the life cycle construct. Entrepreneurship Theory and Practice, 18, 5-30.

Hart, S.L. \& Ahuja, G. 1996. Does it pay to be green? An empirical examination of the relationship between emission reduction and firm performance,Business Strategy and the Environment,5, 30-37.

Hassel, L., Nilsson, H., \& Nyquist, S. 2005. The value relevance of environmental performance. European Accounting Review, 14 (1), 41-61.

Henriques, I., \& Sadorsky, P. 1996. The determinants of an environmentally responsive firm: an empirical approach. Journal of Environmental Economics and Management, 30(3), 381-395.

Helpman, E., Melitz, M. J., \& Yeaple, S. R. 2004. Export versus FDI with heterogeneous firms. American Economic Review, 94(1), 300-316.

Hirschey, M. \& Weygandt, J.J. 1985. Amortization Policy for Advertising and Research and Development Expenditures.Journal of Accounting Research,23(1), 326-335.

Hofmann, K.H., Theyel, G., \& Wood, C.H. 2012. Identifying Firm Capabilities as Drivers of Environmental Management and Sustainability Practices - Evidence from Small and Medium-Sized Manufacturers. Business Strategy and the Environment,21(8) , 530-545.

Hourneaux, F., Hrdlicka, H.A., Gomes, C.M., Kruglianskas, I., 2014. The use of environmental performance indicators and size effect: A study of industrial companies. Ecological Indicators, 36, 205-212.

Hua, X., \& Boateng, A. 2015. Trade Openness, Financial Liberalization, Economic Growth, and Environment Effects in the North-South: New Static and Dynamic Panel Data Evidence. Advances in Sustainability and Environmental Justice, 17, 253-289.

International Organization for Standardization 2019. The ISO survey. $\quad$ https://www.iso.org/the-iso-survey.html. Acessed on 05 October 2020.

Iraldo, F., Testa, F. \& Frey, M.2009. Is an environmental management system able to influence environmental and competitive performance? The case of ecomanagement and audit scheme (EMAS). Journal of Cleaner Production, 17(16), 1444-1452.

Keats, B. W., \& M. A. Hitt. 1988. A Causal Model of Linkages among Environmental Dimensions, Macro-organizational Characteristics, and Performance. Academy of Management Journal, 31, 570-598.

Khanna, M., \& Anton, W.R.Q. 2002. Corporate environmental management: Regulatory and market-based pressures. Land Economics, 78(4) , 539-558.

Khanna, M., \& Damon, L. 1999. EPA's voluntary 33/50 program: impact on toxic releases and economic performance of firms. Journal of Environmental Economics and management, 37, 1-25.

Khanna, T., \& Palepu, K. 2000. The future of business groups in emerging markets: Long-run evidence from Chile. Academy of Management Journal, 43, 268-285.

King, A.A., \& Lenox, M.J. 2001. Does It Really Pay to Be Green? An Empirical Study of Firm Environmental and Financial Performance. Journal of Industrial Ecology, 5(1), 105-116.

Klassen, R.D., \& McLaughlin, C.P. 1996. The impact of environmental management on firm performance. Management Science, 42 (8), 1199-214.

Kliewe, T., Davey, T. \& Baaken, T. 2013. Creating a sustainable innovation environment within large enterprises: a case study on a professional services firm. Journal of Innovation Management, 55-84. 
Konar, S., \& Cohen, M.A. 2001. Does the market value environmental performance? Review of Economics and Statistics, 83(2), 281-289

Kube, R., von Graevenitz, K., Löschel, A. \& Massier, P. 2019. Do voluntary environmental programs reduce emissions? EMAS in the German manufacturing sector. Energy Economics. 84.

Kumar, S., \& Managi, S. 2009. Economics of Sustainable Development: the Case of India, Springer, New York

Kumar, S., \& Shetty, S. 2017. Does environmental performance improve market valuation of the firm: evidence from Indian market? Environmental Economics and Policy Studies, 20(2), 241-260.

Lee, S.Y. \& Klassen, R.D. 2008. Drivers and Enablers That Foster Environmental Management Capabilities in Small and Medium Sized Suppliers in Supply Chains. Productions and Operations Management, 17(6), 573-586.

Lee, C.C., Chiu, Y.B. and Sun, C.H. 2010. The environmental Kuznets curve hypothesis for water pollution: Do regions matter? Energy Policy, 38, 12-23.

Lin, W.L. , Ho, J.A. \&Sambasivan, M. 2019. Impact of Corporate Political Activity on theRelationship Between Corporate SocialResponsibility and Financial Performance:A Dynamic Panel Data Approach. Sustainability, 11,60.

Lindenberg, E. \& Ross, S. 1981. Tobin's q ratio and industrial organization. Journal of Business, 54 (1), 1-32.

Lubatkin, M., \& Shrieves, R. 1986. Towards Reconciliation of Market PerformanceMeasures to Strategic Management Research.Academy of Management Review, 11, 497-512.

Lucas, M.T.\&Noordewier, T.G. 2016. EnvironmentalManagement Practices and Firm Financial Performance: The Moderating Effectof Industry Pollution-Related Factors. International Journal of Production Economics, 175, 24-34.

Makni, R., Francoeur, C., \& Bellavance, F. 2009. Causality between Corporate Social Performance and Financial Performance: Evidence from Canadian Firms. Journal of Business Ethics, 89(3), 409-422.

McWilliams, A., \& Siegel, D. 2001. Corporate social responsibility: a theory of the firm perspective. Academy of Management Review, 26, 117-127.

McWilliams, A., Siegel, D. \& Teoh, S., 1999. Issues in the use of the event study methodology: a critical analysisof corporate social responsibility studies. Organizational Research Methods, 2 (4), 340-365.

Melnyk, S.A., Sroufe, R.P., \& Calantone, R. 2003. Assessing the impact of environmental management systems. Journal of Operations Management, 21(3), 329-351.

Ministry of Finance, Government of India, 2015. Economic Survey 2014-15. Oxford University Press.

Ministry of Finance, Government of India, 2020. Economic Survey 2019-20. Oxford University Press.

Mishra, S., \& Suar, D. 2010. Does Corporate Social Responsibility influence Firm Performance of Indian Companies. Journal of Business Ethics, 95, 571-601.

Nehrt, C. 1996. Timing and intensity effects of environmental investments. Strategic Management Journal, 17 (7), 535-547.

Ohlson, J. 1995. Earnings, Book Values and Dividends in Equity Valuation.Contemporary Accounting Research, 11(2), 661-687.

Pantzalis, C. 2001. Does Location Matter? An Empirical Analysis of Geographic Scope and MNC Market Valuation. Journal of International Business Studies, 32, 133155. 
Pargal, S., \& Wheeler, D. 1996. Informal regulation of industrial pollution in developing countries. Journal of Political Economy, 104(6), 1314-1327.

Porter, M. 1991. American's greening strategy. Scientific American, 264, 168.

Porter, M., \& Van der Linde, C. 1995. Green and competitive. Harvard Business Review, 121-134.

Rassier, D., \& Earnhart, D. 2009. Does the Porter hypothesis explain expected future financial performance? The effect of clean water regulation on the chemical manufacturing firms. Environmental and Resource Economics, 45(3), 353-377.

Reinhardt, F. 1999. Market failure and the environmental policies of firms. Journal of Industrial Ecology, 3(1), 9-21.

Rivera, J. 2002. Assessing a voluntary environmental initiative in the developing world: the Costa Rican Certification of Sustainable Tourism. Policy Sciences, 35(4), 333360.

Robb, A. \& Robinson, D.T. 2009. The Capital Structure decisions of new firms. Available at SSRN: http://dx.doi.org/10.2139/ssrn.1345895

Rosenblum, J., Horvath, A., \& Henrickson, C. 2000. Environmental Implications of Service Industries. Environmental Science and Technology, 34(22), 4669-4676.

Sahu, S.K., \& Narayanan, K. 2011. Determinants of Energy Intensity in Indian Manufacturing Industries: A Firm Level Analysis.Eurasian Journal of Business and Economics, 4 (8), 13-30.

Sarkar, J., \& Sarkar, S. 2012. Corporate governance in India. Sage Publishers, New Delhi

Sariannidis, N., Zafeiriou, E., Giannarakis, G. \& Arabatzis, G. 2013. CO 2 Emissions and Financial Performance of Socially Responsible Firms: An Empirical Survey. Business Strategy and Environment, 22, 109-120.

Shahgholian, A. 2019. Unpacking the relationship between environmental profile and financial profile; literature review toward methodological best practice. Journal of Cleaner Production, doi: https://doi.org/10.1016/j.jclepro.2019.05.365.

Shalit, S., \& Sankar, U. 1977. The Measurement of Firm Size. The Review of Economics and Statistics, 59(3), 290-298.

Shashi, Centobelli, P., Cerchione, R. \& Singh, R. 2019. The impact of leanness and innovativeness on environmental and financial performance: Insights from Indian SMEs. International Journal of Production Economics, doi: 10.1016/j.ijpe.2019.02.011

Shashi, K., Cerchione, R., Centobelli, P. \& Shabani, A. 2018. Sustainability orientation, supply chain integration, and SMEs performance: A causal analysis. Benchmarking: An International Journal.

Singh, M.P., Chakraborty, A., Roy, M. \& Tripathi, A. 2020. Developing SME sustainability disclosure index for Bombay Stock Exchange (BSE) listed manufacturing SMEs in India. Environment, Development and Sustainability, https://doi.org/10.1007/s10668-019-00586-z.

Sinkin, C., Wright, C.J., \& Burnett, R.D. 2008. Eco-efficiency and firm value. Journal of Accounting and Public Policy, 27, 167-176.

Stickney, S., Brown, P., \& Wahlen, J. 2007. Financial Reporting, Financial Statement Analysis and Valuation: A Strategic Perspective. Mason, Ohio: Thomson/SouthWestern Publishing.

Sudha, S. 2020. Corporate environmental performance-financial performance relationship in India using eco-efficiency metrics. Management of Environmental Quality: An International Journal. DOI 10.1108/MEQ-01-2020-0011 
Thomadakis, S.B. 1977. A Value-Based Test of Profitability and Market Structure. The Review of Economics and Statistics, 59(2), 179-185.

Thornton, D., Kagan, R.A., \& Gunningham, N. 2003. Sources of corporate environmental performance. California Management Review, 46 (1), 127-141.

Waddock, S., \& Graves, S. 1997. The Corporate Social Performance- Financial Performance Link. Strategic Management Journal, 18(4), 303-319.

Wagner, M. 2010. The role of corporate sustainability performance for economic performance: A firm level analysis of moderation effects. Ecological Economics, 69(7), 1553-1560.

Wagner, M., Van, P.N., Azomaho, T., \& Wehrmeyer, W. 2002. The relationship between the environmental and economic performance of firms: an empiricalanalysis of the European paper industry. Corporate Social Responsibility and Environmental Management, 9, 133-146.

Walley, N., \& Whitehead, B. 1994. It's not easy being green. Harvard Business Review, 72, 46-52.

Wooldridge, J.M. 2010. Econometric Analysis of Cross Section and Panel Data, MIT Press. Chapter 10.

Zattoni, A., Pedersen, T., \& Kumar, V. 2009. The performance of group affiliated firms during institutional transition: A Longitudinal study of Indian firms. Corporate Governance: An International Review, 17(4), 510-523.

Zhu, Q., Cordeiro, J., \& Sarkis, J. 2013. Institutional pressures, dynamic capabilities and environmental management systems: Investigating the ISO 9000 Environmental management system implementation linkage. Journal of Environmental Management, 114 (15) , 232-242.

Zhu, Q., Geng, Y., Fujita, T. \& Hashimoto, S. 2010. Green supply chain management in leading manufacturers: Case studies in Japanese large companies. Management Research Review, 33(4), 380-392 
Table 1: Descriptive statistics of environmental practices

\begin{tabular}{|c|c|c|c|}
\hline Variable & Measurement (YES $=1 \quad \mathrm{NO}=0)$ & Mean & S.D. \\
\hline GRI & $\begin{array}{llll}\text { The organization } & \text { releases } & \text { GRI } & \text { certified } \\
\text { sustainability reports. } & & & \end{array}$ & 0.392 & 0.441 \\
\hline ISO 14001 & The organization is ISO 14001 certified. & 0.752 & 0.213 \\
\hline $\begin{array}{l}\text { Green } \\
\text { Buildings }\end{array}$ & $\begin{array}{l}\text { The organization uses green buildings, which are } \\
\text { BEE/LEED certified. }\end{array}$ & 0.210 & 0.315 \\
\hline CDM & The firm is running CDM projects. & 0.129 & 0.325 \\
\hline CDP & The firm is part of CDP & 0.219 & 0.417 \\
\hline Envtexp & The firm is incurring environmental expenditure & 0.124 & 0.286 \\
\hline
\end{tabular}

Notes: GRI- Global Reporting Initiative; CDM- Clean Development Mechanism; CDP- Carbon

Disclosure Project; Envtexp- Environmental expenditure 
Table 2: Summary statistics of financial and other characteristics of firms

\begin{tabular}{|c|c|c|c|c|}
\hline Variable & Meaning & Definition & Mean & S.D \\
\hline$R O A$ & $\begin{array}{ll}\text { Return } & \text { on } \\
\text { Assets } & \end{array}$ & $\begin{array}{l}\text { Ratio of net income to } \\
\text { total assets }\end{array}$ & 10.076 & 86.832 \\
\hline$R O E$ & $\begin{array}{ll}\text { Return } & \text { on } \\
\text { Equity } & \end{array}$ & $\begin{array}{l}\text { Ratio of net income to } \\
\text { shareholders' equity }\end{array}$ & 14.533 & 14.887 \\
\hline Tobin $Q$ & $\begin{array}{l}\text { Tobin } Q \text { or } \mathrm{Q} \\
\text { ratio }\end{array}$ & $\begin{array}{l}\text { Ratio of market value of } \\
\text { firm to the replacement } \\
\text { cost of its assets }\end{array}$ & 14.161 & 50.77 \\
\hline$M B V R$ & $\begin{array}{lr}\text { Market } & \text { to } \\
\text { Book } & \text { Value } \\
\text { Ratio } & \end{array}$ & $\begin{array}{l}\text { Ratio of the product of } \\
\text { the number of equity } \\
\text { shares and the closing } \\
\text { price of the share on the } \\
\text { last day of the financial } \\
\text { year to the book value of } \\
\text { equity and reserves }\end{array}$ & 3.003 & 5.962 \\
\hline EV/S & $\begin{array}{l}\text { Excess } \\
\text { Valuation to } \\
\text { Sales Ratio }\end{array}$ & $\begin{array}{l}\text { Ratio of excess of market } \\
\text { value of firm over book } \\
\text { value of assets } \\
\text { normalized by sales. }\end{array}$ & 6.235 & 15.90 \\
\hline EMP & $\begin{array}{l}\text { Environmental } \\
\text { Management } \\
\text { Practice }\end{array}$ & $\begin{array}{l}\text { Sum of EMPs adopted by } \\
\text { a firm }\end{array}$ & 2.56 & 1.95 \\
\hline $\mathrm{ADV}$ & $\begin{array}{l}\text { Advertising } \\
\text { intensity }\end{array}$ & $\begin{array}{l}\text { Ratio of advertising } \\
\text { expenditure to sales }\end{array}$ & 0.0092 & 0.0624 \\
\hline $\mathrm{RD}$ & R\&D intensity & $\begin{array}{l}\text { Ratio of research and } \\
\text { development expenditure } \\
\text { to sales }\end{array}$ & 0.004 & .0219 \\
\hline SG & $\begin{array}{l}\text { Growth of } \\
\text { sales }\end{array}$ & $\begin{array}{l}\text { Salest-Salest-1/ Salest- } \\
1 \times 100\end{array}$ & 28.298 & 12.357 \\
\hline LEV & Leverage & $\begin{array}{l}\text { Long-term debt to total } \\
\text { assets ratio }\end{array}$ & 0.312 & 3.27 \\
\hline $\mathrm{MNC}$ & $\begin{array}{l}\text { Multinational } \\
\text { status }\end{array}$ & $\begin{array}{l}\text { Value of } 1 \text { if company is } \\
\text { MNC else } 0 .\end{array}$ & 0.429 & 0.137 \\
\hline Assetage & $\begin{array}{l}\text { Age of firm's } \\
\text { assets }\end{array}$ & $\begin{array}{l}\text { Net fixed assets/ total } \\
\text { assets }\end{array}$ & 0.603 & 0.192 \\
\hline Sales/asset & $\begin{array}{l}\text { Sales asset } \\
\text { ratio }\end{array}$ & Net sales/ Total assets & 5.612 & 24.26 \\
\hline AGE & Age of firm & $\begin{array}{l}\text { Number of years since } \\
\text { incorporation }\end{array}$ & 33.251 & 26.389 \\
\hline
\end{tabular}


Table 3: Correlation matrix

\begin{tabular}{|c|c|c|c|c|c|c|c|c|c|c|c|c|c|c|}
\hline & $R O A$ & $R O E$ & Tobin $Q$ & $M B V R$ & $\mathrm{EV} / \mathrm{S}$ & $E M P$ & $\mathrm{RD}$ & LEV & $\begin{array}{l}\text { Salesasse } \\
\mathrm{t}\end{array}$ & $\begin{array}{l}\text { Assetag } \\
\text { e }\end{array}$ & SG & $\mathrm{ADV}$ & AGE & MNC \\
\hline$R O A$ & 1 & 0.365 & -0.127 & 0.347 & -0.022 & 0.188 & 0.135 & -0.17 & 0.27 & 0.007 & -0.025 & 0.301 & 0.118 & 0.315 \\
\hline$R O E$ & 0.365 & 1 & -0.008 & 0.19 & 0.079 & 0.097 & 0.063 & -0.123 & 0.162 & -0.044 & -0.014 & 0.196 & 0.037 & 0.145 \\
\hline Tobin $Q$ & -0.127 & -0.008 & 1 & -0.124 & 0.158 & -0.012 & -0.013 & -0.031 & 0.033 & -0.069 & -0.013 & 0.38 & -0.01 & 0.031 \\
\hline$M B V R$ & 0.347 & 0.19 & -0.124 & 1 & 0.031 & 0.191 & 0.092 & -0.083 & 0.214 & -0.011 & -0.001 & 0.405 & 0.217 & 0.261 \\
\hline EV/S & -0.022 & 0.079 & 0.158 & 0.031 & 1 & -0.08 & 0.015 & 0.113 & -0.142 & -0.209 & 0.017 & -0.015 & 0.071 & 0.34 \\
\hline EMP & 0.188 & 0.097 & 0.012 & 0.191 & 0.08 & 1 & 0.118 & -0.089 & 0.054 & 0.165 & -0.023 & 0.244 & 0.044 & 0.222 \\
\hline $\mathrm{RD}$ & 0.135 & 0.063 & -0.013 & 0.092 & 0.015 & 0.118 & 1 & -0.121 & 0.165 & -0.003 & -0.013 & 0.031 & 0.336 & 0.183 \\
\hline LEV & -0.17 & -0.123 & -0.031 & -0.083 & 0.113 & -0.089 & -0.121 & 1 & -0.089 & -0.206 & -0.014 & -0.167 & 0.059 & -0.120 \\
\hline $\begin{array}{l}\text { Sales/asse } \\
\mathrm{t}\end{array}$ & 0.27 & 0.162 & 0.033 & 0.214 & -0.142 & 0.054 & 0.003 & -0.089 & 1 & 0.151 & -0.026 & 0.286 & 0.023 & 0.083 \\
\hline Assetage & 0.007 & -0.044 & -0.069 & -0.011 & -0.209 & 0.165 & -0.003 & -0.206 & 0.151 & 1 & -0.045 & 0.103 & 0.078 & 0.0143 \\
\hline SG & -0.025 & -0.014 & -0.013 & -0.001 & 0.017 & -0.03 & -0.013 & -0.014 & -0.026 & -0.045 & 1 & -0.02 & -0.040 & -0.028 \\
\hline ADV & 0.301 & 0.196 & 0.38 & 0.405 & -0.015 & 0.244 & 0.031 & -0.167 & 0.286 & 0.103 & -0.02 & 1 & 0.084 & 0.336 \\
\hline AGE & 0.118 & 0.037 & -0.01 & 0.217 & 0.071 & 0.044 & 0.336 & 0.059 & 0.023 & 0.078 & -0.040 & 0.084 & 1 & 0.084 \\
\hline MNC & 0.315 & 0.145 & 0.031 & 0.261 & 0.34 & 0.222 & 0.183 & -0.120 & 0.083 & 0.014 & -0.028 & 0.336 & 0.084 & 1 \\
\hline
\end{tabular}

Note: $R O A=$ Return on assets, $R O E=$ Return on equity, $M B V R=$ Market to book value ratio, EV/S= Excess valuation to sales ratio,EMP= Total environmental management practices adopted by firm, RD= R\&D intensity, $\mathrm{LEV}=$ Leverage, Sales/asset= Sales to asset ratio, Assetage= ratio of net fixed assets to total assets, $\mathrm{SG}=\mathrm{Sales}$ growth, ADV= Advertising intensity, Age= number of years since firm's inception, MNC= Multinational Corporation. 
Table 4: Impact of EMPs on profitability

\begin{tabular}{|c|c|c|c|c|}
\hline Variables & \multicolumn{2}{|c|}{ ROA } & \multicolumn{2}{|c|}{ ROE } \\
\hline & $\begin{array}{l}\text { Fixed } \\
\text { Effects } \\
(1) \\
\end{array}$ & $\begin{array}{c}\text { Dynamic } \\
\text { Effects } \\
(2)\end{array}$ & $\begin{array}{l}\text { Fixed } \\
\text { Effects } \\
(3)\end{array}$ & $\begin{array}{c}\text { Dynamic } \\
\text { Effects } \\
(4)\end{array}$ \\
\hline $\mathrm{DV}_{\mathrm{t}-1}$ & & $\begin{array}{c}0.0102 * * * \\
(0.000355)\end{array}$ & & $\begin{array}{l}0.422 * * * \\
(0.00289)\end{array}$ \\
\hline $\mathrm{DV}_{\mathrm{t}-2}$ & & $\begin{array}{l}0.0104^{* * *} \\
(0.000361)\end{array}$ & & $\begin{array}{c}0.163^{* * *} \\
(0.0115)\end{array}$ \\
\hline$E M P$ & $\begin{array}{l}-0.408 \\
(0.779)\end{array}$ & $\begin{array}{l}-0.205 \\
(0.127)\end{array}$ & $\begin{array}{c}-0.0684 \\
(0.278)\end{array}$ & $\begin{array}{c}0.130^{* * *} \\
(0.741)\end{array}$ \\
\hline$E M P_{\mathrm{t}-1}$ & $\begin{array}{l}-0.833 \\
(0.724)\end{array}$ & $\begin{array}{c}0.893 * * * \\
(0.107)\end{array}$ & $\begin{array}{l}-0.318 \\
(0.407)\end{array}$ & $\begin{array}{c}0.325^{* * *} \\
(0.0797)\end{array}$ \\
\hline$E M P_{\mathrm{t}-2}$ & $\begin{array}{l}-0.965 \\
(0.872)\end{array}$ & $\begin{array}{l}1.226^{*} \\
(0.175)\end{array}$ & $\begin{array}{c}0.362 \\
(0.368)\end{array}$ & $\begin{array}{c}0.420^{* * *} \\
(0.148)\end{array}$ \\
\hline $\mathrm{RD}$ & $\begin{array}{c}14.62 \\
(10.78)\end{array}$ & $\begin{array}{l}4.941^{*} \\
(2.542)\end{array}$ & $\begin{array}{c}1.117 \\
(4.189)\end{array}$ & $\begin{array}{l}0.0436 \\
(0.737)\end{array}$ \\
\hline ADV & $\begin{array}{c}2.338^{* *} \\
(1.166)\end{array}$ & $\begin{array}{l}0.555^{* *} \\
(0.0813)\end{array}$ & $\begin{array}{l}0.101^{*} \\
(0.688)\end{array}$ & $\begin{array}{l}0.195 * \\
(0.205)\end{array}$ \\
\hline LEV & $\begin{array}{c}0.373 \\
(0.619)\end{array}$ & $\begin{array}{c}0.0137 \\
(0.0290)\end{array}$ & $\begin{array}{c}0.318^{* * *} \\
(0.1055)\end{array}$ & $\begin{array}{l}0.337 * * * \\
(0.00229)\end{array}$ \\
\hline Sales/Asset & $\begin{array}{c}1.991^{* * * *} \\
(0.129)\end{array}$ & $\begin{array}{c}1.893 * * * \\
(0.000943)\end{array}$ & $\begin{array}{c}0.0378^{* * * *} \\
(0.0120)\end{array}$ & $\begin{array}{c}0.0430 * * * \\
(0.00137)\end{array}$ \\
\hline Assetage & $\begin{array}{c}-37.42^{* * *} \\
(14.08)\end{array}$ & $\begin{array}{c}-27.01 * * * \\
(0.310)\end{array}$ & $\begin{array}{c}-2.209 * * * \\
(0.529)\end{array}$ & $\begin{array}{c}-2.021^{*} \\
(0.115)\end{array}$ \\
\hline SG & $\begin{array}{c}0.000145 \\
(0.000354)\end{array}$ & $\begin{array}{c}0.0000407^{* * *} \\
(0.00018)\end{array}$ & $\begin{array}{c}7.19 \mathrm{e}-0 \\
(0.000258)\end{array}$ & $\begin{array}{c}0.000114 \\
(8.53 \mathrm{e}-05)\end{array}$ \\
\hline MNC & $\begin{array}{c}3.696^{* * *} \\
(0.991)\end{array}$ & $\begin{array}{c}1.313^{*} \\
(2.133)\end{array}$ & $\begin{array}{c}0.820^{*} \\
(1.324) \\
\end{array}$ & $\begin{array}{c}0.408^{* * *} \\
(0.101)\end{array}$ \\
\hline AGE & $\begin{array}{c}0.630 \\
(0.528)\end{array}$ & $\begin{array}{c}0.410^{* * *} \\
(0.0146)\end{array}$ & $\begin{array}{l}-0.0330 \\
(0.0100) \\
\end{array}$ & $\begin{array}{c}0.00243 \\
(0.00440) \\
\end{array}$ \\
\hline Hausman test statistics & $21.35^{* * * *}$ & & $10.82^{* * *}$ & \\
\hline Industry effects & $\mathrm{Y}$ & $\mathrm{Y}$ & $\mathrm{Y}$ & $\mathrm{Y}$ \\
\hline Constant & $\begin{array}{c}-0.932 \\
(5.208) \\
\end{array}$ & $\begin{array}{l}8.070 * \\
(4.194) \\
\end{array}$ & $\begin{array}{l}3.146 * * \\
(1.510) \\
\end{array}$ & $\begin{array}{c}1.088^{* * *} \\
(0.219) \\
\end{array}$ \\
\hline 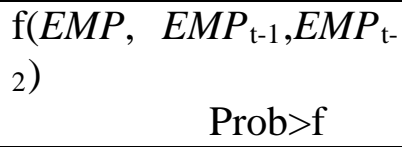 & $\begin{array}{c}0.64 \\
(0.590)\end{array}$ & & $\begin{array}{c}0.64 \\
(0.591)\end{array}$ & \\
\hline 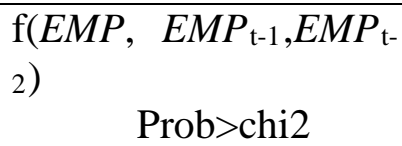 & & $\begin{array}{c}69.49 * * * \\
(0.000)\end{array}$ & & $\begin{array}{c}123.90^{* * *} \\
(0.000)\end{array}$ \\
\hline Sargan test statistics & & 4.204 & & 10.124 \\
\hline $\mathrm{AR}(1)$ & & 0.177 & & 0.924 \\
\hline $\mathrm{AR}(2)$ & & 0.090 & & 0.921 \\
\hline Observations & 3970 & 3480 & 3970 & 3480 \\
\hline Number of companies & 459 & 458 & 459 & 458 \\
\hline
\end{tabular}

Standard errors in parentheses $* * * \mathrm{p}<0.01,{ }^{* *} \mathrm{p}<0.05,{ }^{*} \mathrm{p}<0.1$
Note- $\mathrm{DV}=$ dependent variable, $E M P=$ Total environmental management practices adopted by firm, $\mathrm{RD}=\mathrm{R} \& \mathrm{D}$ intensity, Lev=Leverage, Assetage $=$ ratio of net fixed assets to total assets, $\mathrm{SG}=$ Sales growth, $\mathrm{ADV}=$ Advertising 
intensity, Age= number of years since firm's inception, $\mathrm{MNC}=$ Multinational Corporation, 1/BV=1/Book value, $\mathrm{NI} / \mathrm{BV}=$ Net income/ Book value

Table 5: Impact of EMPs on market valuation

\begin{tabular}{|c|c|c|c|c|c|c|}
\hline Variables & \multicolumn{2}{|c|}{ Tobin $Q$} & \multicolumn{2}{|c|}{$E V / S$} & \multicolumn{2}{|c|}{$M B V R$} \\
\hline & $\begin{array}{c}\text { Fixed } \\
\text { Effects } \\
(1)\end{array}$ & $\begin{array}{c}\text { Dynamic } \\
\text { Effects } \\
(2)\end{array}$ & $\begin{array}{c}\text { Fixed } \\
\text { Effects } \\
\text { (3) }\end{array}$ & $\begin{array}{c}\text { Dynamic } \\
\text { Effects } \\
(4)\end{array}$ & $\begin{array}{c}\text { Fixed } \\
\text { Effects } \\
(5)\end{array}$ & $\begin{array}{c}\text { Dynamic } \\
\text { Effects } \\
(6)\end{array}$ \\
\hline $\mathrm{DV}_{\mathrm{t}-1}$ & & $\begin{array}{l}0.0456 * * * \\
(0.000901)\end{array}$ & & $\begin{array}{c}0.455^{* *} \\
(0.000434)\end{array}$ & & $\begin{array}{c}0.182^{* * *} \\
(0.000583)\end{array}$ \\
\hline $\mathrm{DV}_{\mathrm{t}-2}$ & & $\begin{array}{c}0.00055 \\
(0.210 e-05)\end{array}$ & & $\begin{array}{l}0.0021 * * * \\
(8.90 \mathrm{e}-05)\end{array}$ & & $\begin{array}{l}-6.22 \mathrm{e}-06 \\
(6.40 \mathrm{e}-05)\end{array}$ \\
\hline 1/BV & & & & & $\begin{array}{l}5.528^{*} \\
(3.404)\end{array}$ & $\begin{array}{c}3.48 * \\
(2.281)\end{array}$ \\
\hline NI/BV & & & & & $\begin{array}{l}4.329^{*} \\
(6.409)\end{array}$ & $\begin{array}{l}1.213^{*} \\
(3.626)\end{array}$ \\
\hline$E M P$ & $\begin{array}{c}0.104 \\
(1.434)\end{array}$ & $\begin{array}{l}1.026^{*} \\
(0.398)\end{array}$ & $\begin{array}{c}18.00 \\
(23.41)\end{array}$ & $\begin{array}{c}52.18^{* * *} \\
(14.33)\end{array}$ & $\begin{array}{c}1.529 \\
(1.815)\end{array}$ & $\begin{array}{l}0.0310 \\
(0.194)\end{array}$ \\
\hline$E M P_{\mathrm{t}-1}$ & $\begin{array}{c}1.229 \\
(1.304)\end{array}$ & $\begin{array}{c}1.313 \\
(1.912)\end{array}$ & $\begin{array}{c}11.63 \\
(12.44)\end{array}$ & $\begin{array}{c}17.43 \\
(18.476)\end{array}$ & $\begin{array}{l}-0.0839 \\
(0.966)\end{array}$ & $\begin{array}{l}0.407^{*} \\
(0.231)\end{array}$ \\
\hline$E M P_{\mathrm{t}-2}$ & $\begin{array}{c}0.736 \\
(1.877)\end{array}$ & $\begin{array}{l}0.648^{*} \\
(0.386)\end{array}$ & $\begin{array}{l}2.365^{* *} \\
(9.802)\end{array}$ & $\begin{array}{c}60.00 * * * \\
(15.27)\end{array}$ & $\begin{array}{c}2.145 \\
(1.896)\end{array}$ & $\begin{array}{l}2.185^{*} \\
(1.306)\end{array}$ \\
\hline $\mathrm{RD}$ & $\begin{array}{l}-15.82 \\
(11.89)\end{array}$ & $\begin{array}{l}-40.80^{*} \\
(22.64)\end{array}$ & $\begin{array}{c}-60.9 \\
(42.62)\end{array}$ & $\begin{array}{l}-76.2^{* *} \\
(69.91)\end{array}$ & $\begin{array}{l}-37.65 \\
(26.93)\end{array}$ & $\begin{array}{l}-6.443 \\
(6.643)\end{array}$ \\
\hline ADV & $\begin{array}{c}13.56 * * * \\
(11.27)\end{array}$ & $\begin{array}{c}35.98 * * * \\
(3.003)\end{array}$ & $\begin{array}{c}2.292 * * * \\
(10.91)\end{array}$ & $\begin{array}{c}5.686 * * * \\
(0.509)\end{array}$ & $\begin{array}{l}2.406^{*} \\
(4.772)\end{array}$ & $\begin{array}{c}3.123 * * * \\
(0.370)\end{array}$ \\
\hline LEV & $\begin{array}{l}-1.535 \\
(0.995)\end{array}$ & $\begin{array}{c}0.0454 \\
(0.0306)\end{array}$ & $\begin{array}{l}-22.86 \\
(25.42)\end{array}$ & $\begin{array}{c}3.912 \\
(2.029)\end{array}$ & $\begin{array}{l}-1.355 \\
(1.206)\end{array}$ & $\begin{array}{c}0.260 * * * \\
(0.0594)\end{array}$ \\
\hline Sales/asset & $\begin{array}{l}0.616^{*} \\
(0.521)\end{array}$ & $\begin{array}{l}0.609 * * \\
(0.289)\end{array}$ & $\begin{array}{l}2.837 * * \\
(3.048)\end{array}$ & $\begin{array}{c}2.866^{* * *} \\
(1.777)\end{array}$ & $\begin{array}{l}0.131^{*} \\
(0.135)\end{array}$ & $\begin{array}{l}0.346^{* *} \\
(0.204)\end{array}$ \\
\hline Assetage & $\begin{array}{l}-16.13 \\
(2.617)\end{array}$ & $\begin{array}{c}-15.98 * * * \\
(10.99)\end{array}$ & $\begin{array}{l}-42.03 \\
(42.79)\end{array}$ & $\begin{array}{c}-24.50 * * * \\
(40.36)\end{array}$ & $\begin{array}{l}-10.22 \\
(12.77)\end{array}$ & $\begin{array}{l}-1.058^{*} \\
(0.557)\end{array}$ \\
\hline SG & $\begin{array}{c}0.00631 \\
(0.00236)\end{array}$ & $\begin{array}{c}0.0105 \\
(0.000311)\end{array}$ & $\begin{array}{c}0.113 \\
(0.0484)\end{array}$ & $\begin{array}{c}0.711 \\
(0.000315)\end{array}$ & $\begin{array}{l}0.000748 \\
(0.00165)\end{array}$ & $\begin{array}{c}0.0124 \\
(0.000146)\end{array}$ \\
\hline $\mathrm{MNC}$ & $\begin{array}{c}10.96 \\
(20.65)\end{array}$ & $\begin{array}{c}22.69 * * * \\
(11.22)\end{array}$ & $\begin{array}{c}14.73 \\
(32.56)\end{array}$ & $\begin{array}{c}15.10^{* * *} \\
(5.187)\end{array}$ & $\begin{array}{c}2.894 \\
(7.584)\end{array}$ & $\begin{array}{c}30.94 * * * \\
(5.272)\end{array}$ \\
\hline AGE & $\begin{array}{c}-0.143 \\
(0.0989)\end{array}$ & $\begin{array}{c}-0.574 \\
(0.00721)\end{array}$ & $\begin{array}{l}-1.924 \\
(1.529)\end{array}$ & $\begin{array}{l}-24.81 \\
(0.770)\end{array}$ & $\begin{array}{l}-0.0598 \\
(0.0923)\end{array}$ & $\begin{array}{c}-0.473 \\
(0.0686)\end{array}$ \\
\hline $\begin{array}{c}\text { Hausman } \\
\text { test statistics }\end{array}$ & $72.26 * * *$ & & $13.13^{* *}$ & & $13.24 * * *$ & \\
\hline $\begin{array}{c}\text { Industry } \\
\text { effects }\end{array}$ & $\mathrm{Y}$ & $Y$ & $Y$ & $\mathrm{Y}$ & $\mathrm{Y}$ & $\mathrm{Y}$ \\
\hline Constant & $\begin{array}{c}1.799 * * * \\
(0.615)\end{array}$ & $\begin{array}{c}0.715 \\
(0.806)\end{array}$ & $\begin{array}{c}4.123 * * * \\
(1.028)\end{array}$ & $\begin{array}{l}0.0430 \\
(2.227)\end{array}$ & $\begin{array}{c}1.583 \\
(3.118)\end{array}$ & $\begin{array}{c}1.283 \\
(3.266)\end{array}$ \\
\hline $\begin{array}{c}\text { Sargan test } \\
\text { statistics }\end{array}$ & & 15.86 & & 17.38 & & 25.17 \\
\hline $\mathrm{AR}(1)$ & & 1.496 & & 0.8284 & & 1.224 \\
\hline $\operatorname{AR}(2)$ & & 0.8502 & & 0.7791 & & 0.676 \\
\hline
\end{tabular}




\begin{tabular}{|c|c|c|c|c|c|c|}
\hline Observations & 3970 & 3480 & 3970 & 3480 & 3970 & 318 \\
\hline $\begin{array}{c}\text { Number of } \\
\text { companies }\end{array}$ & 459 & 458 & 459 & 458 & 459 & 458 \\
\hline
\end{tabular}

Standard errors in parentheses *** $\mathrm{p}<0.01, * * \mathrm{p}<0.05, * \mathrm{p}<0.1$

Note- $\mathrm{DV}=$ dependent variable, $E M P=$ Total environmental management practices adopted by firm, $\mathrm{RD}=\mathrm{R} \& \mathrm{D}$ intensity, Lev=Leverage, Assetage= ratio of net fixed assets to total assets, $\mathrm{SG}=$ Sales growth, ADV= Advertising intensity, Age= number of years since firm's inception, $\mathrm{MNC}=$ Multinational Corporation, 1/BV=1/Book value, $\mathrm{NI} / \mathrm{BV}=$ Net income/ Book value 


\section{Appendix}

Table A1: Energy Intensity of industries

\begin{tabular}{|l|l|l|}
\hline Industry & $\begin{array}{l}\text { Ratio of Energy Cost to Net Sales } \\
\text { (Rs. Crore) for 2018-19 }\end{array}$ & Nature \\
\hline Aluminium & 0.1205 & Manufacturing \\
\hline Air Transport & 0.2498 & Service \\
\hline Banking* & & Service \\
\hline Cement & 0.2176 & Service \\
\hline Chlor Alkali & 0.2709 & Manufacturing \\
\hline Copper Smelter** & 0.1009 & Manufacturing \\
\hline Distillery & 0.0078 & Manufacturing \\
\hline Dyes and Dye Intermediary & 0.0493 & Manufacturing \\
\hline Fertilizer & 0.115 & Manufacturing \\
\hline Healthcare & 0.0251 & Service \\
\hline Hotels and Tourism & 0.0493 & Service \\
\hline IT & 0.0066 & Service \\
\hline Iron and Steel & 0.0658 & Manufacturing \\
\hline Oil refinery & 0.0318 & Manufacturing \\
\hline Pesticide & 0.0277 & Manufacturing \\
\hline Petrochemicals & 0.0231 & Manufacturing \\
\hline Pharmaceutical & 0.0302 & Manufacturing \\
\hline Pulp and Paper & 0.1153 & Manufacturing \\
\hline Real Estate & 0.0043 & Service \\
\hline Sugar & 0.0149 & Manufacturing \\
\hline Tanneries & 0.0214 & Manufacturing \\
\hline Telecom & 0.1256 & Service \\
\hline Thermal Power & 0.0142 & Manufacturing \\
\hline Zinc Smelter** & 0.183 & Manufacturing \\
\hline
\end{tabular}

*: For Banks, Power and fuel cost insignificant as compared to turnover.

**: Industries dropped due to small size $($ Firms $<10)$ 
Table A2: Impact of EMPs on profitability in Large scale companies

\begin{tabular}{|c|c|c|c|c|}
\hline & \multicolumn{2}{|l|}{ ROA } & \multicolumn{2}{|l|}{ ROE } \\
\hline & $\begin{array}{l}\text { Fixed Effects } \\
\text { (1) }\end{array}$ & $\begin{array}{l}\text { Dynamic Effects } \\
\text { (2) }\end{array}$ & $\begin{array}{l}\text { Fixed Effects } \\
\text { (3) }\end{array}$ & $\begin{array}{l}\text { Dynamic Effects } \\
\text { (4) }\end{array}$ \\
\hline $\mathrm{DV}_{\mathrm{t}-1}$ & & $\begin{array}{l}0.0288^{* * *} \\
(0.0141)\end{array}$ & & $\begin{array}{l}0.460 * * * \\
(0.00855)\end{array}$ \\
\hline $\mathrm{DV}_{\mathrm{t}-2}$ & & $\begin{array}{l}0.129 * * * \\
(0.00935)\end{array}$ & & $\begin{array}{l}0.170^{* * *} \\
(0.0395)\end{array}$ \\
\hline EMP & $\begin{array}{l}-2.280 \\
(1.889)\end{array}$ & $\begin{array}{l}0.0727 \\
(0.406)\end{array}$ & $\begin{array}{l}-0.0955 \\
(0.173)\end{array}$ & $\begin{array}{l}0.0831 \\
(0.0510)\end{array}$ \\
\hline$E M P_{\mathrm{t}-1}$ & $\begin{array}{l}1.366 \\
(1.634)\end{array}$ & $\begin{array}{l}-0.438 \\
(0.418)\end{array}$ & $\begin{array}{l}-0.318 \\
(0.407)\end{array}$ & $\begin{array}{l}-0.102 \\
(0.135)\end{array}$ \\
\hline$E M P_{\mathrm{t}-2}$ & $\begin{array}{l}0.225 \\
(0.533)\end{array}$ & $\begin{array}{l}0.0151^{*} \\
(0.305)\end{array}$ & $\begin{array}{l}0.362 \\
(0.368)\end{array}$ & $\begin{array}{c}0.0769 * \\
(0.208)\end{array}$ \\
\hline RD & $\begin{array}{l}-8.524 \\
(9.603)\end{array}$ & $\begin{array}{l}-2.619 \\
(5.107)\end{array}$ & $\begin{array}{l}-0.464 \\
(1.585)\end{array}$ & $\begin{array}{l}-0.392 \\
(1.185)\end{array}$ \\
\hline ADV & $\begin{array}{l}2.335^{* * *} \\
(0.781)\end{array}$ & $\begin{array}{l}0.143^{*} \\
(0.840)\end{array}$ & $\begin{array}{l}0.706^{* *} \\
(0.738)\end{array}$ & $\begin{array}{l}0.0269 * \\
(0.249)\end{array}$ \\
\hline LEV & $\begin{array}{l}-0.0425 \\
(0.0358)\end{array}$ & $\begin{array}{l}-0.00213 \\
(0.00245) \\
\end{array}$ & $\begin{array}{l}0.678^{*} \\
(0.351)\end{array}$ & $\begin{array}{l}0.679 * * * \\
(0.0352)\end{array}$ \\
\hline Sales/asset & $\begin{array}{l}2.095^{* * *} \\
(0.0363)\end{array}$ & $\begin{array}{l}1.673^{* * *} \\
(0.0180)\end{array}$ & $\begin{array}{l}0.108^{* * *} \\
(0.0279)\end{array}$ & $\begin{array}{l}0.0247^{* *} \\
(0.0476)\end{array}$ \\
\hline Assetage & $\begin{array}{l}-37.77^{* *} \\
(5.599) \\
\end{array}$ & $\begin{array}{l}-25.41^{* *} \\
(2.251) \\
\end{array}$ & $\begin{array}{l}-0.154^{*} \\
(0.574)\end{array}$ & $\begin{array}{l}-1.965^{*} \\
(1.032)\end{array}$ \\
\hline SG & $\begin{array}{l}-4.30 \mathrm{e}-06 \\
(2.30 \mathrm{e}-05)\end{array}$ & $\begin{array}{l}-2.64 \mathrm{e}-06 \\
(1.64 \mathrm{e}-05)\end{array}$ & $\begin{array}{l}0.000128^{* *} \\
(6.32 \mathrm{e}-05)\end{array}$ & $\begin{array}{l}0.000134^{* *} \\
(5.63 \mathrm{e}-05)\end{array}$ \\
\hline MNC & $\begin{array}{l}-22.07 \\
(19.04)\end{array}$ & $\begin{array}{l}1.464 \\
(1.388)\end{array}$ & $\begin{array}{l}0.307 \\
(0.816)\end{array}$ & $\begin{array}{l}-0.222 \\
(0.898)\end{array}$ \\
\hline AGE & $\begin{array}{l}0.0336 \\
(0.0311)\end{array}$ & $\begin{array}{l}0.0655 \\
(0.124) \\
\end{array}$ & $\begin{array}{l}-0.0131 * * \\
(0.00637)\end{array}$ & $\begin{array}{l}0.0247 \\
(0.0476) \\
\end{array}$ \\
\hline Hausman test statistics & $15.43 * * *$ & & $11.72 * * *$ & \\
\hline Constant & $\begin{array}{l}43.72 * * * \\
(19.93)\end{array}$ & $\begin{array}{l}9.428^{* * *} \\
(3.463)\end{array}$ & $\begin{array}{l}0.859 \\
(0.926)\end{array}$ & $\begin{array}{l}2.649 * \\
(1.595)\end{array}$ \\
\hline Sargan test statistics & & 3.683 & & 10.41 \\
\hline $\mathrm{AR}(1)$ & & 0.1577 & & 0.8594 \\
\hline $\mathrm{AR}(2)$ & & 0.0798 & & 0.8960 \\
\hline Observations & 9656 & 7874 & 9656 & 7874 \\
\hline Number of companies & 1439 & 1437 & 1439 & 1437 \\
\hline
\end{tabular}

Standard errors in parentheses ${ }^{* * *} \mathrm{p}<0.01,{ }^{* *} \mathrm{p}<0.05,{ }^{*} \mathrm{p}<0.1$ 